Article

\title{
Cross-Regional Highway Built through a City Centre as an Example of the Sustainable Development of Urban Transport
}

\author{
Magdalena Żak and Anna Mainka *(D) \\ Department of Air Protection, Faculty of Energy and Environmental Engineering, \\ Silesian University of Technology, 44-100 Gliwice, Poland; Magdalena.Zak@polsl.pl \\ * Correspondence: Anna.Mainka@polsl.pl; Tel.: +48-322-371-060
}

Received: 29 October 2020; Accepted: 10 December 2020; Published: 12 December 2020

check for updates

\begin{abstract}
Sustainable development requires ensuring the mobility of residents and must not cause deterioration of the quality of the environment in the selected area. The purpose of this study is to verify if the construction of a cross-regional highway through the city centre affected air quality in the neighbourhood of a newly built road. Air quality was assessed based on measurements of concentrations of nitrogen dioxide, which is considered to be typical for automotive sources air pollution. The spectrophotometric method with passive sampling was used in the $24 \mathrm{~h} \mathrm{NO}_{2}$ measurements. The calculated mean $\mathrm{NO}_{2}$ concentrations in the periods before and after road construction were within the ranges of $23.2-31.9 \mu \mathrm{g} / \mathrm{m}^{3}$ and $22.3-28.9 \mu \mathrm{g} / \mathrm{m}^{3}$, respectively. The relative $\mathrm{NO}_{2}$ concentrations determined in the study for 10 out of 11 sampling points were lower than the unity, including 5 points markedly lower $(0.82-0.89)$. The obtained results indicate that the construction of the new artery by the city centre, using appropriate technical solutions and traffic organization (tunnel, noise barriers, roundabouts, speed limit) likely contributed to an overall reduction in $\mathrm{NO}_{2}$ concentrations. The presented solution may serve as an example for other cities struggling with problems of low air quality associated with inefficient transportation systems.
\end{abstract}

Keywords: road transport; cross-regional highway; transport pollutants; nitrogen dioxide

\section{Introduction}

Currently, transport is one of the most substantial issues for cohesive policy in the European Union (EU). Following the EU budgetary summit (21 July 2020), of the EUR 750 billion allocated to the Reconstruction Fund for the years 2021-2027, Poland obtained EUR 124 billion for programmes and investments involving energy, environmental protection and transport. The allocation of significant funds for the development of road infrastructure is connected with the ecological nuisance of transport. In urban areas, road transport is probably the most environmentally hazardous source of air pollution [1]. The types of moving vehicles and the traffic intensity (as well as fluency of movement) are the factors which have an impact on pollutant concentration recorded in urban air [2].

The development of civilization has caused a constant increase in the number of cars. In 1990, the number of passenger cars in the EU was almost 164 million, while in 2010 it was almost 242 million. Furthermore, between 2015 and 2018, the total number of cars in the EU increased by $6.5 \%$ [3]. In Poland, the number of cars increased by $12.5 \%$, due to the growth in gross domestic product (GDP) [3], and in the Silesia Province (Poland), it increased by 9.5\% [4]. Forecasts show that by 2050, the worldwide emissions from road transport, due to the doubling of the number of cars [5], will increase from $40 \%$ to $70 \%$, depending on the pollutant [6].

Among the numerous pollutants emitted by motor transport, nitrogen oxides $\left(\mathrm{NO}_{\mathrm{x}}\right)$ comprise the largest share of total transport emissions [2]. Among the $\mathrm{NO}_{\mathrm{x}}$ emitted from transport, the dominant 
share belongs to $\mathrm{NO}$, but in ambient air, $\mathrm{NO}$ is easily converted to $\mathrm{NO}_{2}$ [7]. $\mathrm{NO}_{2}$ is biochemically more active and more toxic than $\mathrm{NO}$ [8]. It is a strong oxidising agent, like $\mathrm{O}_{3}$, although it is less reactive. As an oxidant, it acts on proteins causing damage to respiratory tissues [9]. Many literature studies concerning the impact of $\mathrm{NO}_{2}$ on humans underline the effects of exposure to high concentrations [10-12]. However, the epidemiological data indicate that even low doses of $\mathrm{NO}_{2}$ can cause irritation to the throat and oral mucosa, as well as conjunctiva, which can lead to tracheobronchitis and other non-allergic respiratory diseases $[13,14]$. High concentrations of $\mathrm{NO}_{2}$ in atmospheric air promote the occurrence of respiratory, cardiovascular and cerebrovascular diseases and increased mortality $[15,16]$. Children, foetuses, the elderly and persons with pre-existing respiratory diseases are especially vulnerable to increased concentrations of $\mathrm{NO}_{x}$, causing an increased risk of asthma, respiratory tract symptoms and reduced lung function growth and enhancing the allergic response [17-19]. Moreover, a correlation between increased $\mathrm{NO}_{2}$ concentrations in the air and an increase in the number of hospitalisations was found [19-21].

To assess the health threat of $\mathrm{NO}_{2}$, its ambient levels have been monitored at many locations around the world. National air quality monitoring systems are frequently based on continuous on-line monitors located at one sampling site. However, these monitors cannot provide spatial variations in $\mathrm{NO}_{2}$ levels over a greater geographical area. In order to measure the spatial distribution of the concentration of selected pollutants, passive samplers are an ideal tool [7]. The advantages of passive samplers include their small dimensions, low weight, simple maintenance and the lack of supply requirements. Moreover, the method offers precision, determination of low concentrations and the possibility of eliminating the influence of atmospheric conditions [2].

With the development of civilization, an increase in the number of cars has been observed, but at the same time, there is a need to improve ambient air quality. Therefore, a sustainable development policy must be followed. Policies for the sustainable development of transport focus on three factors that influence the citizens' acceptance of environmentally friendly transport:

- Car use reduction,

- Transport taxes and

- Popularisation of public transport.

In Poland, environmental awareness is still so low that these factors would not gain public acceptance. An analysis of the mobility of Poles indicates that the car is most frequently used for travelling (above $80 \%$ ). This is due to the shorter commuting times by car than by other means of transport [22].

One of the options for reducing city traffic is the development of ring roads. However, this solution mainly concerns transit and freight transport and has only a minor influence on city-centre traffic. The problem of limiting local traffic is particularly important in large cities and conurbations. A response to this problem could be the construction of cross-regional highways.

Since a change in traffic policy requires a high investment, research demonstrating the likely positive environmental effect of any investment is needed. Therefore, research is needed to prove the positive environmental effect of the planned investment. To correctly estimate the planned investment, modelling tools are particularly helpful. As described in [23], many tools are available to model yearly, daily and hourly particulate matter (PM) and $\mathrm{NO}_{2}$ concentrations at street level, taking into account urban topography, emission performance of vehicles, the composition of the vehicle fleet, the daily activity patterns and background pollution. Additionally, activity-based models can cover a nationwide region, while still providing sufficient detail to assess effects on a local scale and for different population subgroups [24]. As an example, the results from the SHERPA-city application can be recommended [25] or an activity-based model that illustrates the impact of different trip motives on $\mathrm{PM}_{10}$ and $\mathrm{O}_{3}$ concentrations as well as the intra-daily $\mathrm{NO}_{2}$ cycle [26].

One of the possibilities to investigate the effects of opening a new road is to make use of a "natural experiment," in which a change in pollutants' concentrations can be monitored [27]. The objective 
of this paper is to verify how the building of a highway through the centre of a city inhabited by 180,000 residents will affect the ambient air quality in the vicinity of the newly built artery. The specific aim of the study is to evaluate of the impact of constructing a cross-regional highway (DTS) in Gliwice (Poland) on air pollution by measuring the levels of $\mathrm{NO}_{2}$ in the ambient air at a number of points along the course of the DTS.

\section{Materials and Methods}

\subsection{Study Area}

The sampling campaigns were conducted in the city located in Metropolis GZM (Górnoślaskko-Zagłębiowska Metropolia, Silesian Province, Poland). This urban agglomeration comprises 41 municipalities and is inhabited by nearly 2.3 million people. There are 20 similar conurbations in Europe, inhabited by 1 to 3 million people $[28,29]$.

The most critical transportation routes in Europe run through Metropolis GZM (Figure 1). The intersection of two of the main Polish motorways (A1 and A4) occurs here, and these are the key corridors connecting Western and Eastern Europe, as well as Northern and Southern Europe. The existence of such a transportation network in this area makes Metropolis GZM an unrivalled region in terms of the carriage of goods by means of road transport [30].

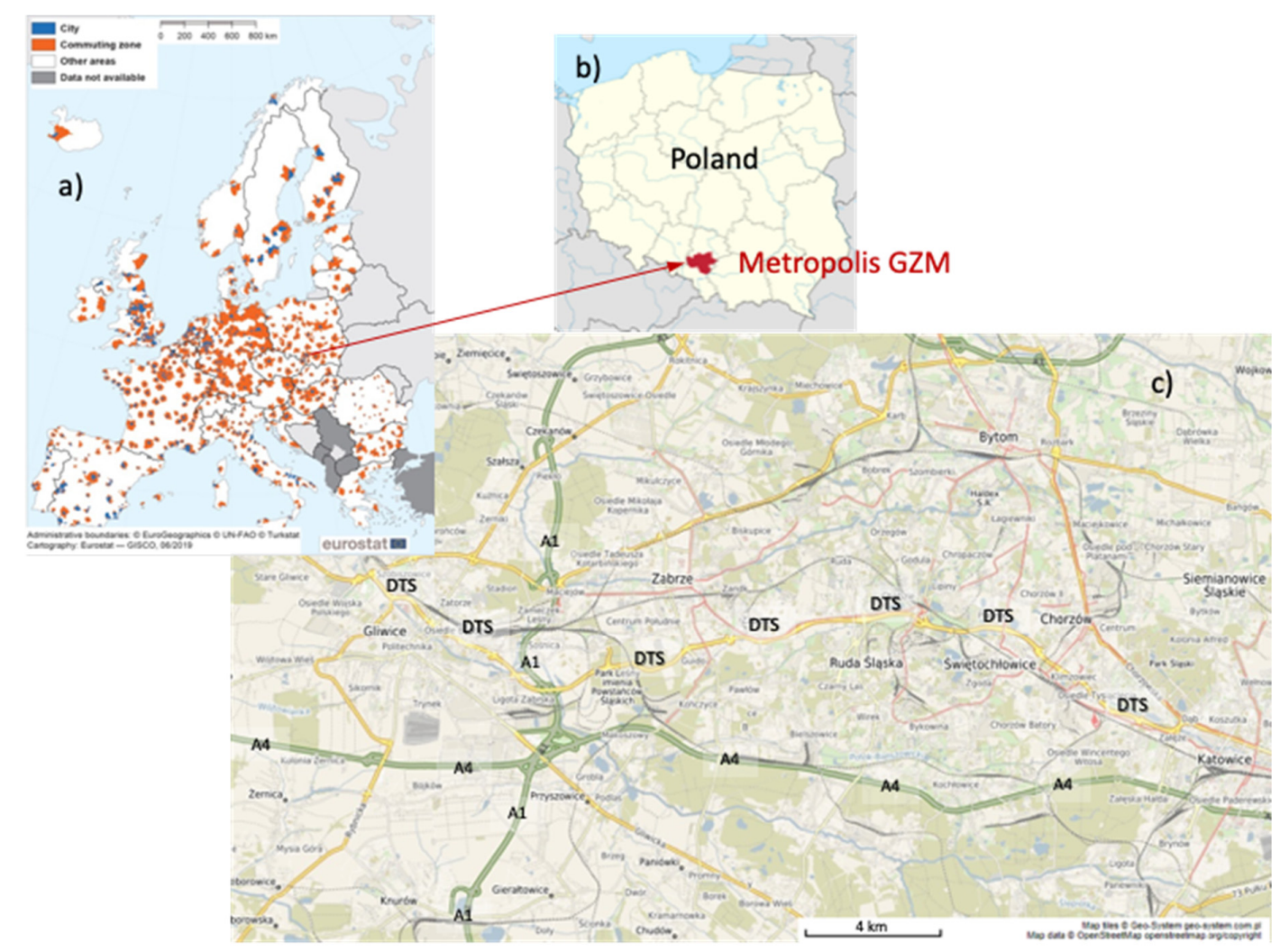

Figure 1. (a) Cities and commuting zones in Europe (2018); (b) location of Metropolis GZM in Poland; (c) route of main roads in Metropolis GZM.

The task of the Metropolis GZM internal transportation system is to support local traffic, as well as external traffic, associated with access to the sites located in the Metropolis, constituting as much as $88 \%$, while the remaining $12 \%$ is accounted for by transit traffic [31]. According to the aforementioned data, the key problem in the region presented is intra-regional transport. An inefficient transportation system often runs past dense buildings and therefore has low traffic fluency, especially in residential and industrial areas. The road surfaces, often in poor technical condition, result in average speeds 
of approximately 15 to $17 \mathrm{~km} / \mathrm{h}$. Such a traffic situation causes a high accident rate and a high environmental burden, associated with high emissions of transport-related air pollutants.

The response to these problems was the construction of a cross-regional highway (DTS) as the main transportation artery of Metropolis GZM. This road became a "transportation backbone" of the central part of GZM, running through the downtown centres of Katowice, Chorzów, Świętochłowice, Ruda Ślaska, Zabrze and Gliwice. Of the cities mentioned, the biggest challenge for DTS construction was in Gliwice, due to the plan to build the road through the city centre. Compared to other cities in the region, Gliwice is characterised by an increased level of car traffic, as it is an important academic, scientific, medical and industrial centre. By assumption, the purpose of the DTS Gliwice section was to support local traffic.

The construction plans of the DTS in Gliwice provoked much controversy among the citizens. The concerns were mainly related to the increase in car traffic in the city centre, the emission of pollutants from vehicles and transportation noise. The chosen solution in Gliwice was a road of $8.1 \mathrm{~km}$ in length that included (1) a single-carriageway with four lanes, (2) a dual carriageway with two lanes and (3) a dual carriageway with three lanes in each direction [31]. Limiting the "circulation" along the city road network became possible due to the dense distribution of road junctions. The section in Gliwice includes 16 road junctions, located every $1.3 \mathrm{~km}$ on average (Figure 2) [31]. The two turbo-roundabouts at one sampling point are shown in red, while conventional roundabouts are shown in green.

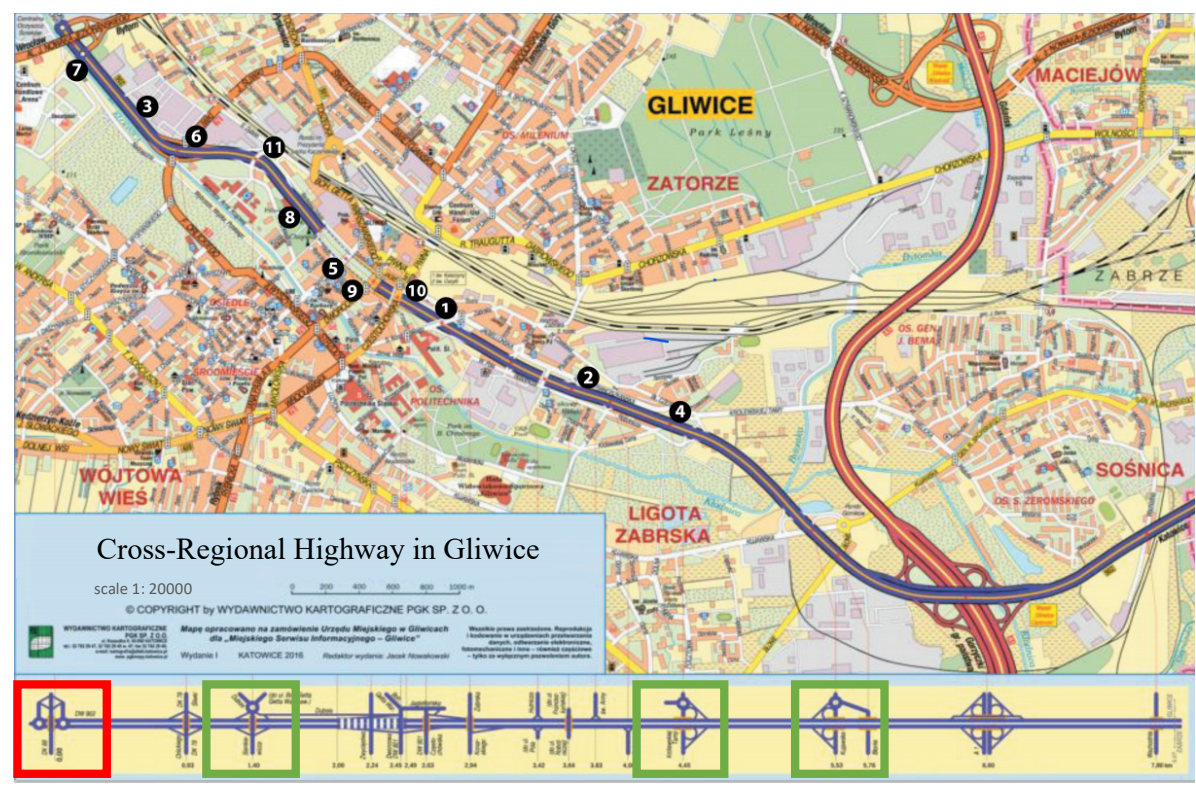

Figure 2. Location of sampling points (No. 1-11) along the cross-regional highway in Gliwice.

\subsection{Characteristics of Sampling Points}

The collection of samples was carried out during two campaigns: before the DTS construction (performed from April to May 2012 (labelled B)) and after opening the DTS (from May to July 2016 (labelled A)). The sampling was performed at 11 measuring points along the DTS in Gliwice. Seven of them (Nos. 1-7) were located next to existing streets, intersections or road junctions in the immediate vicinity of the DTS. These points were characterised by heavy or medium traffic, leading urban traffic in an $\mathrm{E} / \mathrm{W}$ direction (from the eastern border of the city to the DK88 national road, leading traffic to the A4 highway). Three points (Nos. 8-10) were situated next to existing roads with negligible traffic, while point No. 11 was located in an area distant from roads, until the DTS was put into use. A detailed characterisation of sampling points before and after the change of traffic organisation is presented in Table S1. 


\subsection{Sample Collection and Preparation}

A passive sampling method was used for $\mathrm{NO}_{2}$ collection in accordance with the Polish Standard PN-89-Z-04009/08 [32]. This method is based on the Japanese method of Amaya-Sugiura. Absorption of nitrogen dioxide took place on Whatman absorbent paper (23 $\mathrm{mm}$ diameter), soaked with an absorbing solution and placed inside a box passive sampler. Before exposure, the absorbent paper was treated with $0.1 \mathrm{~mL}$ of $20 \%(\mathrm{~m} / \mathrm{m})$ triethanolamine aqueous solution. The details concerning absorbing solution and its chemical reactions with $\mathrm{NO}_{2}$ were presented by Żak et al. [1], following [33-35].

Each sampling point was equipped with one set of passive samplers, including three samplers. The samplers were suspended at a height of about $1.5 \mathrm{~m}$ above ground level and $2 \mathrm{~m}$ from the edge of the road. Sampling time lasted for $24 \mathrm{~h}$, and then after exposure, the samplers were transported to the laboratory.

\subsection{Spectrophotometric Sample Analysis}

Preparing the samples for spectrophotometric analysis involved removing the Whatman papers from the samplers. Each absorbent paper was then leached by Saltzman solution and, after at least $15 \mathrm{~min}$, the extract was analysed by the spectrophotometric technique. The measurements of ray absorption were taken using a SHIMADZU UV-2101 PC spectrophotometer (Shimadzu Corporation, Japan) at a wavelength of $540 \mathrm{~nm}$. The obtained absorbance values were referred to a prepared calibration curve. Sodium nitrite extra pure (Merck) was used as a standard solution for calibration purposes. Each calibration solution was prepared by dilution at $0.05 \mathrm{mg} \mathrm{NO}_{2}^{-}$ions $/ \mathrm{cm}^{3}$ stock solution with ultrapure, distilled water.

The calculated mass of nitrite ions in the tested solutions was used to calculate the average concentration of $\mathrm{NO}_{2}$ during $24 \mathrm{~h}$ exposure. The $24 \mathrm{~h}$ concentration of $\mathrm{NO}_{2}$ was calculated according to the formula presented in [32]. According to the standard [32], $24 \mathrm{~h} \mathrm{NO} \mathrm{N}_{2}$ concentration was calculated as an arithmetic mean of the concentrations obtained from the set of three samplers. Any values which differed from the arithmetic mean by more than $20 \%$ were rejected.

The accuracy of $\mathrm{NO}_{2}$ concentrations determined via the spectrophotometric method, with passive sample collection, was about $10 \%$, and the limit of detection (LOD) during the 24-h sampling time was $2 \mu \mathrm{g} / \mathrm{m}^{3}$ [36]. All of the reagents needed for both stage sampling and subsequent analysis were prepared according to the principles described in [32].

\section{Results}

The mean temperatures, relative humidity and wind speeds during the two measurement periods before (B) and after (A) the DTS construction were $8.4{ }^{\circ} \mathrm{C}, 66.4 \%$ and $1.1 \mathrm{~m} / \mathrm{s}$ and $18.9{ }^{\circ} \mathrm{C}, 66.8 \%$ and $0.7 \mathrm{~m} / \mathrm{s}$, respectively. It is expected that meteorological parameters are interlinked in various ways with $\mathrm{NO}_{2}$ levels in ambient air. However, it is difficult to assess the effect of each separate meteorological factor on $\mathrm{NO}_{2}$ pollution. Studies involving analysis of $\mathrm{NO}_{2}$ ambient levels as a function of meteorological parameters strongly depend on local factors [37-39]. According to [40], the $\mathrm{NO}_{2}$ concentration is slightly higher at a lower relative humidity, whereas other authors found that the $\mathrm{NO}_{2}$ concentration correlates positively with the relative humidity in all seasons, especially during winter [41]. A negative correlation between wind speed and $\mathrm{NO}_{2}$ concentration was found by [42-44]. However, their analysis, constructed by averaging pollutant concentration by wind speed, used the following categories: $0-1 \mathrm{~m} / \mathrm{s}, 1-2 \mathrm{~m} / \mathrm{s}$, etc. or $<2 \mathrm{~m} / \mathrm{s}$ and $>2 \mathrm{~m} / \mathrm{s}$. As can be seen, differences in humidity and wind speed between the periods are small and likely insignificant. On the other hand, the difference in temperature between both sessions was $10.5^{\circ} \mathrm{C}$. However, the relation between $\mathrm{NO}_{2}$ and temperature was inconsistent. The correlation was found to be insignificant or weak [43,45], but other studies found strong positive correlations between the $\mathrm{NO}_{2}$ concentration and temperature for all seasons [41]. Research studies [37,40,46] underline that the seasonal variation in $\mathrm{NO}_{2}$ is only evident when comparing summer/spring with fall/winter. The lifetime of $\mathrm{NO}_{2}$ decreases from 4.2 to 
$3.2 \mathrm{~h}$ between the spring and summer [47]. Thus, on average, afternoon concentrations of $\mathrm{NO}_{2}$ are less in the summer than in the spring. However, the $\mathrm{NO}_{2}$ concentrations used in this study are $24 \mathrm{~h}$ averages, which are less affected by the change in lifetime, which is driven by seasonal changes in daytime $\mathrm{OH}$ concentrations.

During both sampling campaigns, a total of 561 samples were collected to determine $24 \mathrm{~h}$ concentrations of $\mathrm{NO}_{2}$. After the initial verification of the results, $4.4 \%$ of $\mathrm{NO}_{2}$ concentrations (which differed $>20 \%$ from the arithmetic mean concentrations) were rejected. However, the removal of the outliers does not materially affect the results. In total of $536 \mathrm{NO}_{2}$ concentration values were used for the final statistical analysis. Mean values of the $24 \mathrm{~h}$ concentrations (treated as a database attributed to a given sampling point) were statistically analysed to interpret the results obtained. Some statistics, like standard deviation, relative standard deviation and skewness (a measure of the asymmetry of the observed results, which describes the shape of the resulting pattern around the mean in each sampling point) are presented in Table 1 (before the DTS construction) and Table 2 (after the DTS construction).

Table 1. Statistical characteristics of $24 \mathrm{~h} \mathrm{NO}_{2}$ concentrations in ambient air measured at sampling points Nos. 1-11 before the DTS construction (B).

\begin{tabular}{ccccc}
\hline Sampling Point & Mean Value $\left(\mu \mathrm{g} / \mathbf{m}^{3}\right)$ & SD $\left(\mu \mathrm{g} / \mathbf{m}^{3}\right)$ & RSD $(\%)$ & Skewness \\
\hline 1 & 25.4 & 3.1 & 12.3 & -0.38 \\
2 & 26.9 & 6.0 & 22.3 & 0.87 \\
3 & 28.8 & 7.2 & 24.9 & -1.07 \\
4 & 23.2 & 4.7 & 20.2 & -0.42 \\
5 & 29.4 & 8.8 & 29.9 & -0.13 \\
6 & 26.8 & 7.3 & 27.3 & -0.98 \\
7 & 31.9 & 5.6 & 17.6 & -1.10 \\
8 & 25.0 & 6.3 & 25.4 & -1.24 \\
9 & 26.8 & 7.7 & 28.6 & -1.02 \\
10 & 24.6 & 5.5 & 22.2 & 0.29 \\
11 & 23.8 & 5.1 & 21.3 & 0.14 \\
\hline
\end{tabular}

Table 2. Statistical characteristics of $24 \mathrm{~h} \mathrm{NO}_{2}$ concentrations in ambient air measured at sampling points Nos. 1-11 after the DTS construction (A).

\begin{tabular}{ccccc}
\hline Sampling Point & Mean Value $\left(\mathrm{g} / \mathbf{m}^{3}\right)$ & SD $\left(\mu \mathrm{g} / \mathbf{m}^{3}\right)$ & RSD $(\%)$ & Skewness \\
\hline 1 & 22.3 & 1.8 & 8.1 & -1.04 \\
2 & 24.0 & 3.2 & 13.2 & 0.35 \\
3 & 28.9 & 4.3 & 15.0 & 0.61 \\
4 & 22.9 & 3.4 & 14.7 & 1.27 \\
5 & 25.1 & 3.8 & 15.1 & 0.12 \\
6 & 26.6 & 5.0 & 18.8 & 0.11 \\
7 & 26.2 & 4.1 & 15.6 & -0.34 \\
8 & 24.7 & 2.3 & 9.5 & -0.04 \\
9 & 22.3 & 3.3 & 14.8 & -0.07 \\
10 & 23.7 & 2.7 & 11.3 & -0.03 \\
11 & 26.3 & 3.8 & 14.3 & 0.37 \\
\hline
\end{tabular}

None of the mean values of $24 \mathrm{~h}$ concentrations exceeded the permissible concentration level, equal to $40 \mu \mathrm{g} / \mathrm{m}^{3}$ [48]. Mean concentrations ranged from $58 \%$ to $80 \%$ and from $56 \%$ to $72 \%$ of the permissible concentration level for measuring periods (B) and (A), respectively.

The diversity in traffic intensity and engine operating conditions at each sampling point, as well as variable meteorological conditions, led to the variability of the measured concentrations. Mean values of $24 \mathrm{~h} \mathrm{NO}_{2}$ concentrations at all sampling points for series performed before the DTS construction (B) varied from $23.2 \mu \mathrm{g} / \mathrm{m}^{3}$ to $31.9 \mu \mathrm{g} / \mathrm{m}^{3}$. The lowest $24 \mathrm{~h} \mathrm{NO}_{2}$ concentration was recorded at sampling point No. 4. This point is surrounded by a green, non-usable area (Table S1) and is characterised by 
medium traffic intensity. Such topographical conditions ensure the adequate dispersion of pollutants. The highest $24 \mathrm{~h} \mathrm{NO}_{2}$ concentration during sampling series (B) was measured at sampling point No. 7 located near a road junction. It was one of the critical transportation nodes for the city, including the traffic to and from the city in a northerly direction (Figure 2). This node, consisting of two intersections, was always heavily laden with traffic, caused by a stream of cars, trucks and buses. The failure of the (B) road system created frequent road congestion, affecting the high emission of pollutants associated with unfavourable engine operating conditions, such as deceleration, stopping and accelerating.

At all sampling points, the mean values of $24 \mathrm{~h} \mathrm{NO}_{2}$ concentrations measured after the DTS construction (A) varied from $22.3 \mu \mathrm{g} / \mathrm{m}^{3}$ to $28.9 \mu \mathrm{g} / \mathrm{m}^{3}$. The lowest $24 \mathrm{~h} \mathrm{NO} \mathrm{NO}_{2}$ concentration was found at sampling point No. 1. Before the DTS construction, it was one of the most traffic-laden roads for vehicles entering the city centre district. The traffic on this road decreased significantly, and there are now entry and exit roads to and from the DTS at the beginning and the end of this road. The implemented solution led to the transfer of traffic to the newly built DTS to a large extent. The highest $24 \mathrm{~h} \mathrm{NO}_{2}$ concentration was reported at sampling point No. 3 during the sampling of series (A). This point was on the road in which the DTS currently runs. Before opening the DTS, it was a two-lane road, loaded with heavy traffic. It is now a four-carriageway road, but still with heavy traffic in terms of cars, trucks and buses. Additionally, in the long section, this road was constructed without acoustic screens, which can promote the dispersion of pollutants.

\section{Discussion}

To find out whether and how the construction of the DTS through the city centre affected the quality of the air in the vicinity of the newly opened road, the $24 \mathrm{~h}$ concentrations of $\mathrm{NO}_{2}$ were determined at each sampling point. The mean of the $24 \mathrm{~h}$ concentrations was obtained before and after DTS construction (i.e., the (B) and (A) measurement periods, respectively). These concentrations were used to evaluate the impact of changing the traffic organisation on ambient air quality. For this purpose, the concentrations measured after putting the DTS into use (A) were compared to concentrations determined at the same sampling points before the construction of the DTS in the city (B). Assuming the concentration (B) period to be 1.0 for all sampling points and comparing the concentrations from period (A), we obtain the relative concentrations presented in Figure 3.

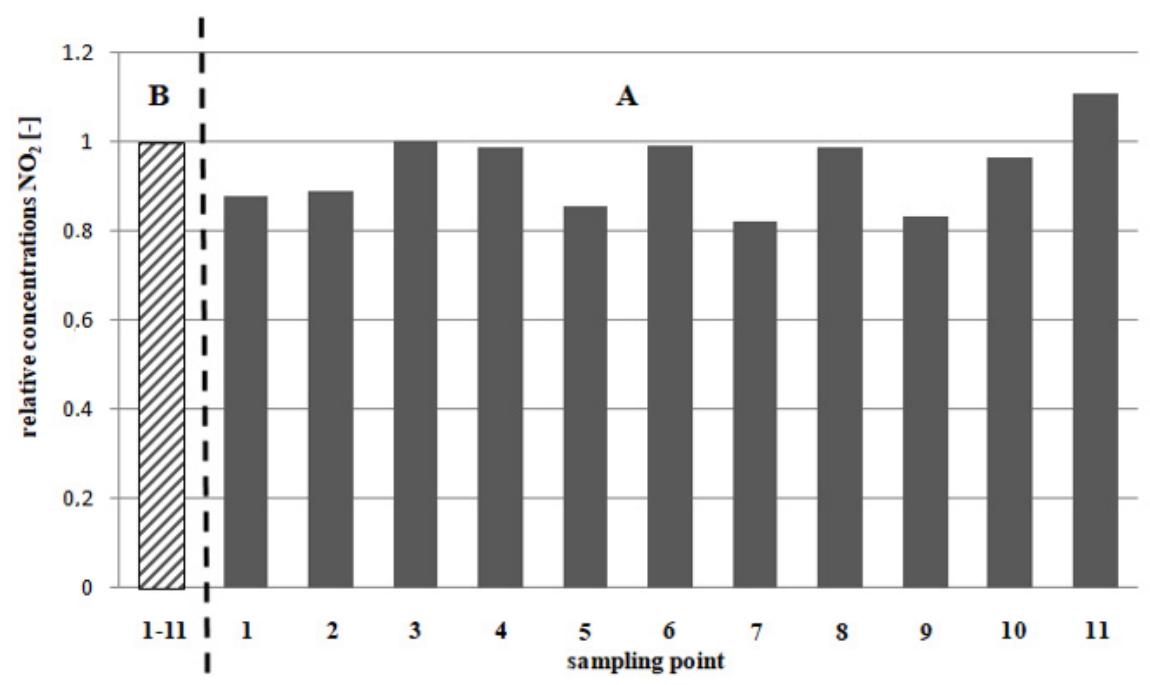

Figure 3. The $\mathrm{NO}_{2}$ relative concentrations in sampling points before the cross-regional highway (DTS) construction (B) and after DTS construction (A).

The comparison of relative concentrations shows that, for the vast majority of sampling points (Nos. 1-10), even a partial transfer of traffic to a nearby DTS had a positive effect on the $\mathrm{NO}_{2}$ concentration levels measured along the existing roads. At these points (Nos. 1-10), the concentrations 
of $\mathrm{NO}_{2}$ decreased. Only at one point (No. 11) was an increase of mean $24 \mathrm{~h} \mathrm{NO}$ concentration found compared to the initial situation (B).

Based on the change in size and nature of $\mathrm{NO}_{2}$ concentrations, sampling points can be divided into three categories, characterised by:

- A clear decrease in concentrations (change $>10 \%$ ),

- A slight decrease in concentrations (change $<5 \%$ ) and

- An increase in concentrations.

The first of these groups includes points Nos. 1, 2, 5, 7 and 9, in which concentrations decreased by $11 \%$ to $18 \%$. Sampling point No. 1 was located on the street which, before the construction of the DTS, was the access road to the city centre, characterised by high traffic. Currently, the traffic has moved to the DTS, which runs in parallel to this street at a distance of about $70 \mathrm{~m}$. Change of traffic organisation has resulted in a reduction in traffic and a decrease in the mean $\mathrm{NO}_{2}$ concentration by more than $12 \%$.

A similar decrease in concentration (11\%) was found at sampling point No. 2. Before the change in traffic organisation, this road was characterised by medium traffic. It is now close to the DTS (approximately $10 \mathrm{~m}$ ) and is separated from the surroundings by acoustic screens with a height of about $8 \mathrm{~m}$. Movement of traffic on the DTS and the use of acoustic screens resulted in a decrease in $\mathrm{NO}_{2}$ concentrations.

Sampling points Nos. 5 and 9 were located in streets which, before the construction of the DTS (B), were characterised by high traffic due to the fact that they were the main access roads to the city centre (city market), as well as exit roads towards the north and west. The traffic has now moved to the DTS, which leads to a tunnel (Figure 4). The tunnel is $493 \mathrm{~m}$ long and 10 to $20 \mathrm{~m}$ wide. Moreover, the entrance and exit of the tunnel are 100 to $200 \mathrm{~m}$ away from both points, so sampling points Nos. 5 and 9 are not directly exposed to pollution coming from the DTS tunnel; the mean $\mathrm{NO}_{2}$ concentrations dropped by nearly $15 \%$ and $17 \%$, respectively.

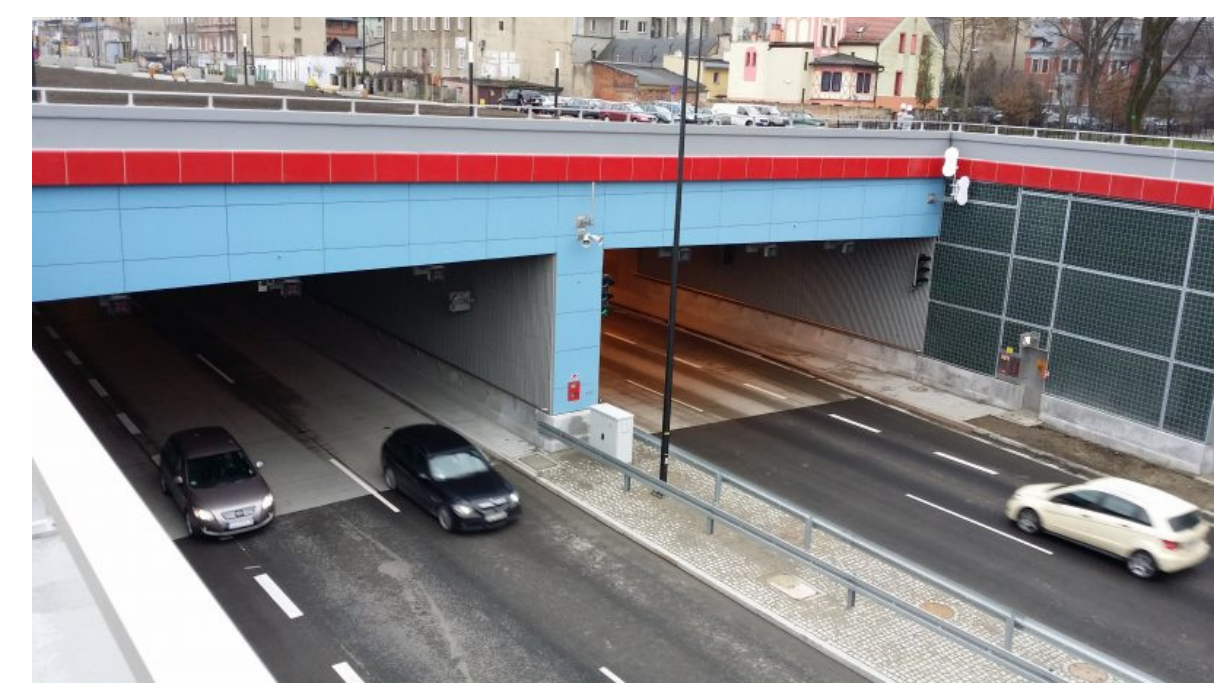

Figure 4. Photograph of the tunnel after DTS construction (A).

Sampling point No. 7 was located next to the road, situated between two road junctions which have been changed into two turbo-roundabouts. Before the reconstruction (B), as well as after (A), this section was characterised by very high traffic due to its direct proximity to the entry/exit to the DK 88 road. The previous arrangement of entries and exits to DK 88 caused frequent traffic jams and lack of traffic flow. The new turbo-roundabouts enabled free-flowing traffic and the mean $\mathrm{NO}_{2}$ concentration at point No. 7 decreased by nearly $18 \%$.

Sampling points 3, 4, 6, 8 and 10 form a second group. At these points, the concentrations of $\mathrm{NO}_{2}$ decreased between $0.3 \%$ and $3.4 \%$. Among these locations, before the construction of DTS (B), 
points Nos. 3, 4 and 6 were characterised by medium or high traffic and the presence of traffic lights (point No. 6), which limited the traffic flow. The construction of the cross-regional highway (A) resulted in the transfer of traffic from the existing roads to the nearby DTS. Although the intensity of the car flow throughout the DTS increased, the concentrations of $\mathrm{NO}_{2}$ were not significantly higher. The mean $24 \mathrm{~h}$ concentration of $\mathrm{NO}_{2}$ at this point represents $65 \%$ of the permissible concentration value. The achieved effect is most likely due to the fluent movement of vehicles.

Only one sampling point (No. 11, located nearby the Oncology Centre) belongs to the third category; an almost $11 \%$ increase in the mean $24 \mathrm{~h}$ concentration of $\mathrm{NO}_{2}$ was found. The sampling point is located at the newly created roundabout connecting the DTS with three other roads. It should be noted that this case does not point to a negative role of DTS on air quality. Before changing the traffic organisation, this point was located in a green area, near streets with low, local traffic. A noticeable increase in car traffic at point No. 11 is now (A) associated with commuting to the Oncology Centre. Annually, the number of hospitalised patients in the Oncology Centre exceeds 35,000, while the number of outpatient advice reaches approximately 194,000 on average [49]. Previously (B) the main access road to this healthcare facility led though the narrow street from the west side of the city. Currently, DTS is the basic access road for the Oncology Centre patients and employees.

We now explore the five factors that played a role in the improved air quality after construction of the DTS:

- The imposition of a speed limit of $70 \mathrm{~km} / \mathrm{h}$,

- The dense network of DTS entrances and exits,

- The tunnel,

- The roundabout and

- The noise barriers.

The imposition of a speed limit: In order to reduce emissions from cars moving along the DTS in the Gliwice city centre and along roads in densely built-up areas, the obligatory vehicle speed limit was set at $70 \mathrm{~km} / \mathrm{h}$. The impact of speed management on the environment, from the point of view of fuel consumption, pollutant emissions and noise emissions, is widely described in the literature [50-53]. Research on pollutant emissions indicates that the dependence of the average vehicle speed on CO and $\mathrm{HC}$ road emissions has a minimum value, corresponding to an average vehicle speed of $75 \mathrm{~km} / \mathrm{h}$. In the case of $\mathrm{NO}_{\mathrm{x}}$, the speed increase above $100 \mathrm{~km} / \mathrm{h}$ causes a significant increase in emissions of these pollutants; however, below this speed, emissions remain at a relatively low level [54-56]. Research by Andrzejewski [55] indicates the possibility of further reducing road emissions at a speed of $70 \mathrm{~km} / \mathrm{h}$ by driving in higher gears, i.e., at lower engine speeds. The beneficial effect of lower engine load on the pollutant emission rate also applies to speeds other than $70 \mathrm{~km} / \mathrm{h}$.

The dense network of DTS entrances and exits: The dense distribution of road entrances and exits to and from the DTS (including 16 road junctions), located in the city centre every $1.3 \mathrm{~km}$, on average, limits the "circulation" along the city road network beyond the DTS [31].

Tunnels: Sustainable development of transport infrastructure in areas with strong urbanisation requires the construction of road tunnels. This solution improves road transportation and acts as a barrier to the spread of solid and gaseous pollutants and noise on the surface above the tunnel [42]. A study [57] on the effect of a new road tunnel on the concentration and distribution of traffic-related air pollution, specifically $\mathrm{NO}_{2}$, showed that, although the tunnel intervention did not lead to consistent reductions in $\mathrm{NO}_{2}$ over the more comprehensive study area, the analysis of passive sampler data indicated that the most significant reductions in $\mathrm{NO}_{2}$ concentrations occurred within $100 \mathrm{~m}$ of the existing road. Moreover, tunnels are the most effective means of reducing noise and air pollution as well as the visual intrusion of infrastructure screening; however, they are the most expensive [58].

Roundabouts: At intersections, vehicles usually decelerate or stop, causing disruption to the traffic flow, whereas roundabouts improve the traffic flow. They encourage the flow of traffic and the reduction of intersection collisions [59]. Moreover, they improve local air quality, and the costs of landscaping are 
relatively low $[60,61]$. The classic roundabout is formed around a central island in the shape of the circle. The alternative to the standard roundabout is a turbo-roundabout, created when the circle is divided into two semicircles and displaced along the axis of the roundabout by the width of the traffic lane [62]. A comparison between the two-lane roundabout and the turbo-roundabout, in terms of $\mathrm{NO}_{\mathrm{x}}$ emissions, points to the fact that the increase in average speed by $38 \%$, under morning congestion conditions, results in a $31 \%$ reduction in the emission of $\mathrm{NO}_{x}$. In the evenings, when the traffic is definitely lighter, an increase in the average speed of $8 \%$ for turbo-roundabouts causes a $21 \%$ decrease in the $\mathrm{NO}_{\mathrm{x}}$ emissions [63]. The VERSIT + Enviver emission model [63] shows that small roundabouts reduce $\mathrm{NO}_{\mathrm{x}}$ by $21 \%$ [60]. On the contrary, the studies by $[64,65]$ point out that that vehicles at turbo-roundabouts generated more $\mathrm{NO}_{\mathrm{x}}(12 \%-19 \%)$ than vehicles at the conventional multi-lane roundabouts (depending on the car flow) and 33\% more $\mathrm{NO}_{\mathrm{x}}$ than signalised intersections $[59,66]$. As can be seen, there is no consensus about the benefits of turbo-roundabouts regarding the available capacity of the intersection. In our studies, we observed a decrease in $\mathrm{NO}_{2}$ concentration at turbo-roundabouts (point No. 7), which indicates the role of fluent road traffic in improving air quality.

Noise barriers: Various studies have looked at the impact of noise barriers on the dilution and dispersion of air pollution. For example, [67] reported that noise barriers reduce concentrations of nitrogen oxides $\left(\mathrm{NO}_{\mathrm{x}}\right)$ and airborne particulates along motorways. The results show that if the barriers are present on both sites of the highway, the area affected by car emissions does not extend a considerable distance in the lee of the road.

$\mathrm{NO}_{\mathrm{x}}$ is highly concentrated between barriers and decreases much faster with the distance from the road edge than without a barrier. The possibility of reducing $\mathrm{NO}$ and $\mathrm{NO}_{2}$ concentrations is seen in the use of photocatalytic processes. The CEDR report (Conference of European Directors of Roads) [68] highlights the potential of using $\mathrm{TiO}_{2}$ coatings for photocatalytic reduction of $\mathrm{NO}_{\mathrm{x}}$ applied to noise barriers [69]. Comparison of the modelling measurements concerning the use of such barriers [70] indicates that more than $30 \%$ of the $\mathrm{NO}_{\mathrm{x}}$ reduction is possible at vehicle level, with an overall pollution reduction of $10 \%-20 \%$. On the other hand, the examples of practical trials of $\mathrm{TiO}_{2}$ coatings underline the reduced effectiveness in real conditions, as well as higher costs than ordinary noise barriers [68].

It can be assumed that the reduction of concentrations measured in 2016 compared to 2012 may be influenced not only by the actions presented earlier (construction of DTS with the whole infrastructure), but also by the change of the vehicle fleet during these four years. The age of a vehicle certainly has an impact on pollutant emissions, including $\mathrm{NO}_{2}$, as newer models meet the increasingly rigorous Euro standards and pollute the environment to a lesser extent. The Euro 6 standard valid form September 2015 enforced a significant reduction of $\mathrm{NO}_{\mathrm{x}}$ from diesel engines (ZS) (a 67\% reduction) compared to Euro 5, while for petrol ones (ZI), the standard had not been exacerbated [71]. However, the Polish car fleet has a very unfavorable age structure compared to other European countries with a significant share of old cars. During four analyzed years, the number of new cars increased slightly $(0.8 \%)$, the number of cars aged 3-15 years decreased ( $8.7 \%$ ), while the number of the oldest cars ( $>16$ years) increased $(7.4 \%)$. In case of trucks and buses, this structure is also unfavorable [72,73]. With such old vehicles, often in poor technical condition, it is difficult to suppose that 4 years of difference in the measurement period will have a significant impact on the observed changes in pollutant concentrations, due to the fleet turnover.

\section{Strengths and Limitations}

From the perspective of several years of using the DTS, the authorities of Gliwice City consider that the DTS road meets expectations. Residents use this road, and the traffic on the DTS is growing. In 2016, the number of cars passing through the tunnel was about 30,000 per day. Current usage, on an average working day, is 37,000 cars [74]. This means that more and more people are choosing DTS instead of going through the city. This effectively reduces traffic in the city centre. The new road is also used by patients of the Institute of Oncology in Gliwice. It is crucial for an institution of such importance to have the right access roads. Road connections to many other places in Gliwice have 
also been improved, including the Silesian University of Technology and the subzone of Katowice Special Economic Zone [75]. There are several traffic solutions in the city, which play a significant role in changing the habits of the residents (who now choose DTS more often than local roads). There is also the unique (in eastern Europe) intelligent traffic control system (ITS Gliwice), which, by the signs with variable content, provides information about the time of arrival to the city centre (Figure 5). The system optimises traffic in Gliwice and ensures a fluent passage in a shorter time. The additional innovation of ITS in Gliwice is to give public transport buses the priority of passing through crossings with traffic lights. Based on the same devices, a system gives absolute priority to privileged vehicles (police, ambulance and the fire brigade).

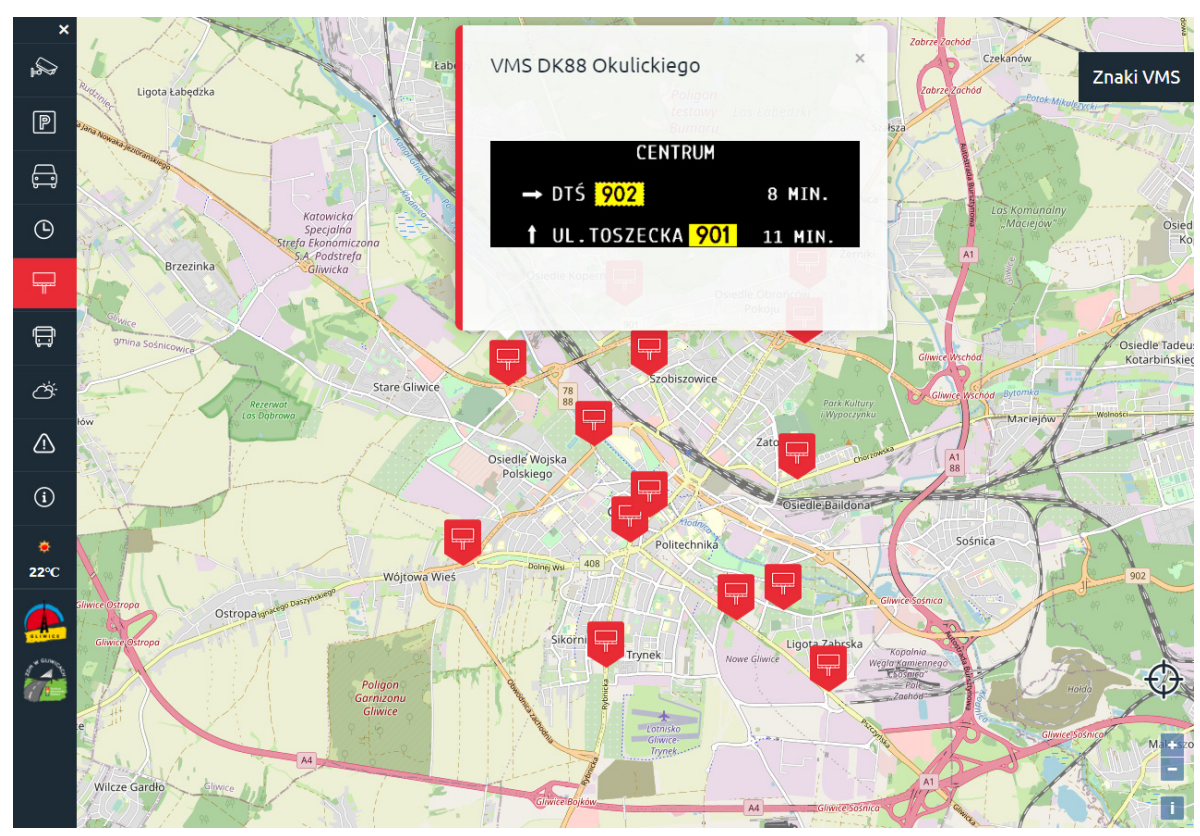

Figure 5. Example information displayed by Intelligent Traffic System Gliwice.

The DTS has a length of $31.3 \mathrm{~km}$, connecting Gliwice with Katowice-the capital of the Metropolis GZM - and it ensures convenient and safe movement between densely populated areas of the Metropolis and improves accessibility to the most critical facilities, located mainly in the downtown zone. The collision-free course of the DTS on the Katowice-Gliwice section and its high technical parameters reduce the length of the road by $26 \%$, travelling time by $76 \%$, fuel consumption by $47 \%$ and road accidents by $82 \%$ and allow a significant reduction in environmental pollution [31] compared to former road connections.

In Gliwice, the distance that had to be driven within the city borders in the east-west direction was $9.4 \mathrm{~km}$ before 2012, and after the road was built (2016), the distance is $8.1 \mathrm{~km}$. Shortening this distance leads to a reduction in $\mathrm{NO}_{2}$ emissions from vehicles and a reduction in the environmental burden of this pollution. Moreover, the construction of the road, due to its highway character, allowed for the reduction of engine idling and the amount of stops and accelerations. Driving between the city borders in the east-west direction in the old road system (until 2012), one encountered 10 large intersections, including 8 with traffic lights and 1 railroad crossing. Currently, traffic on the DTS is very fluent, and unfavourable operating conditions have been minimized.

Burns et al. [76], in a comprehensive review, presented four groups of interventions to reduce ambient air pollution and their effects on human health (industrial, residential, multiple and vehicular). Among vehicular interventions implemented in the cities to reduce ambient air pollution, infrastructure changes or road reconstructing represents one of seven groups. The other transport-related interventions included speed limit changes, low-emission zones, even-odd restrictions, charging schemes, public transport restructuring and comprehensive traffic reduction strategies. The first infrastructure 
intervention [77] included closing and reconstructing $400 \mathrm{~m}$ of the street in the centre of Ljubljana municipality for all traffic except public buses and taxis as an abatement measure. In comparison to our intervention, this was much smaller and did not result in significant improvement in $\mathrm{NO}_{2}$ concentrations; the $\mathrm{NO}_{2}$ was reduced from 29 to $27 \mu \mathrm{g} / \mathrm{m}^{3}$. The second intervention [57] included building a $3.6 \mathrm{~km}$ tunnel linking two major roadways, along with concomitant road changes to a nearby main road to reduce traffic, including lane number reduction and a dedicated bus lane. The study [57] from 2006 to 2008 showed that the tunnel intervention resulted in an $8.1 \%$ reduction in $\mathrm{NO}_{2}$ concentration, which is comparable to our results. The third intervention [27] included the opening of the by-pass road. The authors of this study underline that the opening of the by-pass led to a reduction in atmospheric pollution in the congested streets, with a proportionate reduction of the lower concentrations in the uncongested streets. However, their research was based on $\mathrm{PM}_{10}$ and $\mathrm{PM}_{2.5}$ reduction.

A limitation of this study is that it focuses on air quality based on $\mathrm{NO}_{2}$ concentrations. Moreover, our study does not include the period of DTS construction (from January 2013 to March 2016). Some studies underline the environmental impact of greenhouse gasses (GHG), particularly $\mathrm{CO}_{2}$, as well as $\mathrm{NO}_{\mathrm{x}}$ and $\mathrm{PM}$, which were generated during highway or tunnel construction [78-80].

Although $\mathrm{NO}_{2}$ is a good indicator of air pollution caused by transportation, it would have been interesting to also include the measurement of noise or other air pollutants, such as $\mathrm{O}_{3}$ or particulate matter (PM), particularly the fine fraction $\left(\mathrm{PM}_{2.5}\right)$. It is worth continuing the measurement in the future and including winter campaigns. Future research could also include the role of an intelligent traffic control system on ambient air quality in Gliwice city.

Another limitation of the presented data in the article is the lack of information on the change of shares of cars and trucks moving on DTS and surrounding roads in the period before and after the construction of this road, but such data are not available. Such information would be valuable in analyzing the impact of a possible change in cars and trucks shares on the $\mathrm{NO}_{2}$ levels, because, as the literature data indicate, $\mathrm{NO}_{\mathrm{x}}$ truck emissions are much larger than car emissions [81,82].

\section{Conclusions}

Car traffic on the Gliwice section of the DTS did not cause deterioration of the air quality along its route and, on the contrary, there was a decrease in mean $24 \mathrm{~h} \mathrm{NO}_{2}$ concentrations by $0.3 \%$ to $18 \%$ compared to the period before the DTS construction.

The specific road solutions used in the DTS construction included replacing crossings with roundabouts, building noise barriers and a tunnel below the strict city centre. Turbo-roundabouts achieved the highest decrease in $24 \mathrm{~h} \mathrm{NO}_{2}$ concentration at a point located nearby. The effect of such an apparent reduction $(18 \%)$ in $\mathrm{NO}_{2}$ concentration, compared to the previous intersection-based road system, was achieved by increasing traffic flow in this road section.

The second effective solution proved to be the construction of a tunnel in the centre of the city. Despite a significant increase in traffic in the studied area, the applied solution allowed a $15 \%$ reduction of $\mathrm{NO}_{2}$ concentration above the tunnel, compared to the road situation before the construction of the DTS.

An increase in the mean $24 \mathrm{~h} \mathrm{NO}_{2}$ concentration by nearly $11 \%$ was found only at one sampling point. Before the construction of the DTS, this point was located in green areas away from busy roads but is now located next to the newly built DTS, which has become a primary access road to the nearby health centre with significant importance for the southern region of Poland. Despite the increase in concentration, the permissible $\mathrm{NO}_{2}$ concentration level was not exceeded.

The reasonableness of the implemented transportation solution, which involves conducting a cross-regional highway through the city centre, is confirmed by the positive opinions of the city authorities and, above all, the residents, who previously expressed doubts at the design stage regarding the adverse environmental effects of such a road solution. 
Supplementary Materials: The following are available online at http://www.mdpi.com/2071-1050/12/24/10403/s1, Table S1: Characteristics of the sampling points.

Author Contributions: Conceptualization, M.Ż. and A.M.; methodology, M.Ż.; formal analysis, M.Ż.; investigation, M.Ż.; resources, M.Ż.; data curation, M.Ż.; writing—original draft preparation, M.Ż. and A.M.; writing一review and editing, M.Ż. and A.M.; visualization, M.Ż. and A.M. All authors have read and agreed to the published version of the manuscript.

Funding: This research was funded by statutory research by the Faculty of Energy and Environmental Engineering, Silesian University of Technology.

Acknowledgments: The authors would like to thank the students Katarzyna Machalica and Michalina Zygmunt, who carried out the measurements in the framework of their Master's thesis, as well as the Municipal Road Administration in Gliwice and Municipal Information Service Gliwice for the data sharing.

Conflicts of Interest: The authors declare no conflict of interest.

\section{References}

1. Żak, M.; Melaniuk-Wolny, E.; Widziewicz, K. The exposure of pedestrians, drivers and road transport passengers to nitrogen dioxide. Atmos. Pollut. Res. 2017, 8, 781-790. [CrossRef]

2. Żak, M.; Loster, A.; Melaniuk-Wolny, E.; Kozielska, B. Air contamination with nitrogen dioxide in the vicinity of Gliwice transport routes before opening the A4 motorway fragment Kleszczow-Gliwice. Arch. Environ. Prot. 2007, 33, 3-15.

3. ACEA (European Automobile Manufacturers Association) Report: Vehicles in Use-Europe 2019. Available online: https:/www.acea.be/statistics/tag/category/report-vehicles-in-use (accessed on 30 September 2020).

4. GUS (Statistical Office) Production. Construction. Investments. Fixed Assets. Transport. Available online: https://katowice.stat.gov.pl/en/information-about-voivodship/voivodship-385/productionconstruction-investments-fixed-assets-transport/ (accessed on 30 September 2020).

5. Times Poland Ile Jest Samochodów na Świecie? Available online: https://polskatimes.pl/ile-jest-samochodowna-swiecie/ar/10496459 (accessed on 30 September 2020).

6. Kiba-Janiak, M.; Witkowski, J. Sustainable urban mobility plans: How do they work? Sustainability 2019, 11, 4605. [CrossRef]

7. Hagenbjörk, A.; Malmqvist, E.; Mattisson, K.; Sommar, N.J.; Modig, L. The spatial variation of $\mathrm{O}_{3}, \mathrm{NO}_{\text {, }}$ $\mathrm{NO}_{2}$ and $\mathrm{NO}_{\mathrm{x}}$ and the relation between them in two Swedish cities. Environ. Monit. Assess. 2017, $189,161$. [CrossRef] [PubMed]

8. Manahan, S.E. Toksykologia Środowiska-Aspekty Chemiczne i Biochemiczne Environmental Toxicology. Chemical and Biochemical Aspects; PWN: Warszawa, Poland, 2006. (In Polish)

9. Hood, D.B.; Gettins, P.; Johnson, D.A. Nitrogen dioxide reactivity with proteins: Effects on activity and immunoreactivity with $\alpha$-1-proteinase inhibitor and implications for $\mathrm{NO}_{2}$-mediated peptide degradation. Arch. Biochem. Biophys. 1993, 304, 17-26. [CrossRef] [PubMed]

10. Santana, J.C.C.; Miranda, A.C.; Yamamura, C.L.K.; Filho, S.C.D.; Tambourgi, E.B.; Ho, L.L.; Berssaneti, F.T. Effects of air pollution on human health and costs: Current situation in São Paulo, Brazil. Sustainability 2020, 12, 4875. [CrossRef]

11. Hesterberg, T.W.; Bunn, W.B.; McClellan, R.O.; Hamade, A.K.; Long, C.M.; Valberg, P.A. Critical review of the human data on short-term nitrogen dioxide $\left(\mathrm{NO}_{2}\right)$ exposures: Evidence for $\mathrm{NO}_{2}$ no-effect levels. Crit. Rev. Toxicol. 2009, 39, 743-781. [CrossRef]

12. Morrow, P.E. Toxicological data on NOx: An overview. J. Toxicol. Environ. Health 1984, 13, 205-227. [CrossRef]

13. Guarnieri, M.; Balmes, J.R. Outdoor air pollution and asthma. Lancet 2014, 383, 1581-1592. [CrossRef]

14. Ghermandi, G.; Fabbi, S.; Veratti, G.; Bigi, A.; Teggi, S. Estimate of Secondary $\mathrm{NO}_{2}$ Levels at Two Urban Traffic Sites Using Observations and Modelling. Sustainability 2020, 12, 7897. [CrossRef]

15. Sheehan, M.C.; Lam, J.; Navas-Acien, A.; Chang, H.H. Ambient air pollution epidemiology systematic review and meta-analysis: A review of reporting and methods practice. Environ. Int. 2016, 92, 647-656. [CrossRef] [PubMed]

16. Public Health England. The Effects of Long-Term Exposure to Ambient Air Pollution on Cardiovascular Morbidity: Mechanistic Evidence. A Report by the Committee on the Medical Effects of Air Pollutants; COMEAP, Public Health England: London, UK, 2018. 
17. Pénard-Morand, C.; Raherison, C.; Charpin, D.; Kopferschmitt, C.; Lavaud, F.; Caillaud, D.; Annesi-Maesano, I. Long-term exposure to close-proximity air pollution and asthma and allergies in urban children. Eur. Respir. J. 2010, 36, 33-40. [CrossRef] [PubMed]

18. Laumbach, R.J.; Kipen, H.M. Respiratory health effects of air pollution: Update on biomass smoke and traffic pollution. J. Allergy Clin. Immunol. 2012, 129, 3-11. [CrossRef] [PubMed]

19. Carvalho, P.C.; Nakazato, L.F.; Nascimento, L.F.C. Exposure to $\mathrm{NO}_{2}$ and children hospitalization due to respiratory diseases in Ribeirão Preto, SP, Brazil. Cienc. Saude Coletiva 2018, 23, 2515-2522. [CrossRef] [PubMed]

20. Pintarić, S.; Zeljković, I.; Bodrožić-Džakić, T.; Vrsalović, M.; Zekanović, D.; Pintarić, H. Correlation between atmospheric air pollution by nitrogen dioxide meteorological parameters and the number of patients admitted to the Emergency Department. Acta Clin. Croat. 2012, 51, 9-15. [PubMed]

21. Mills, I.C.; Atkinson, R.W.; Kang, S.; Walton, H.; Anderson, H.R. Quantitative systematic review of the associations between short-term exposure to nitrogen dioxide and mortality and hospital admissions. BMJ Open 2015, 5, e006946. [CrossRef]

22. Komornicki, T. Geographical Studies No. 227 Transformations in the Daily Mobility of Poles against the Background of Development of Car Ownership; Instytut Geografii i Przestrzennego Zagospodarowania PAN im. Stanisława Leszczyckiego: Warszawa, Poland, 2011.

23. Degraeuwe, B.; Pisoni, E.; Christidis, P.; Christodoulou, A.; Thunis, P. SHERPA-city: A web application to assess the impact of traffic measures on $\mathrm{NO}_{2}$ pollution in cities. Environ. Model. Softw. 2021, 135, 104904. [CrossRef]

24. Dhondt, S.; Kochan, B.; Beckx, C.; Lefebvre, W.; Pirdavani, A.; Degraeuwe, B.; Bellemans, T.; Int Panis, L.; Macharis, C.; Putman, K. Integrated health impact assessment of travel behaviour: Model exploration and application to a fuel price increase. Environ. Int. 2013, 51, 45-58. [CrossRef]

25. Degrauewe, B.; Pisoni, E.; Peduzzi, E.; de Meij, A.; Monforti-Ferrario, F.; Bodis, K.; Mascherpa, A.; Astorga-Llorens, M.; Thunis, P.; Vignati, E. Urban $\mathrm{NO}_{2}$ Atlas; Publications Office of the European Union: Luxembourg, 2019.

26. Lefebvre, W.; Degrawe, B.; Beckx, C.; Vanhulsel, M.; Kochan, B.; Bellemans, T.; Janssens, D.; Wets, G.; Janssen, S.; de Vlieger, I.; et al. Presentation and evaluation of an integrated model chain to respond to trafficand health-related policy questions. Environ. Model. Softw. 2013, 40, 160-170. [CrossRef]

27. Burr, M.L.; Karani, G.; Davies, B.; Holmes, B.A.; Williams, K.L. Effects on respiratory health of a reduction in air pollution from vehicle exhaust emissions. Occup. Environ. Med. 2004, 61, 212-218. [CrossRef]

28. Eurostat European Cities 2. Available online: https://ec.europa.eu/eurostat/documents/3217494/10095393/KSHA-19-001-EN-N.pdf/d434affa-99cd-4ebf-a3e3-6d4a5f10bb07 (accessed on 10 September 2020).

29. Eurostat. Eurostat Regional Yearbook, 2019 ed.; Publications Office of the European Union: Luxembourg, 2019.

30. PwC Advisory. The Socio-Economic Potential of Metropolis GZM. Available online: http://metropoliagzm. pl/wp-content/uploads/2019/02/GZM_raport.pdf (accessed on 6 October 2020).

31. DTŚ, S.A. Information about the Katowice-Gliwice Cross-Regional Highway (DTS). Available online: http://www.portalsamorzadowy.pl/plikiu/79266.html (accessed on 6 October 2020).

32. PKN. PN-Z-04009-08: Air Purity Protection, Tests for Nitric Acid and Nitrogen Oxides. Determination of Nitrogen Dioxide in Ambient Air (Imision) by Spectrophotometric Method with Passive Sampling; Polish Committee for Standarization: Warsaw, Poland, 1989.

33. Glasius, M.; Carlsen, M.F.; Hansen, T.S.; Lohse, C. Measurements of nitrogen dioxide on Funen using diffusion tubes. Atnospheric Environ. 1999, 33, 1177-1185. [CrossRef]

34. Varshney, C.K.; Singh, A.P. Passive samplers for $\mathrm{NO}_{\mathrm{x}}$ monitoring: A critical review. Environmentalist 2003, 23, 127-136. [CrossRef]

35. Hafkenscheid, T.; Fromage-Mariette, A.; Goelen, E.; Hangartner, M.; Pfeffer, U.; Plaisance, H.; de Santis, F.; Saunders, K.; Swaans, W.; Tang, Y.S.; et al. Review of the Application of Diffusive Samplers for the Measurement of Nitrogen Dioxide in Ambient Air in the European Union|EU Science Hub. Available online: https://ec.europa.eu/jrc/en/publication/eur-scientific-and-technical-research-reports/ review-application-diffusive-samplers-measurement-nitrogen-dioxide-ambient-air-european (accessed on 6 October 2020).

36. Kozielska, B.; Mainka, A.; Żak, M.; Kaleta, D.; Mucha, W. Indoor air quality in residential buildings in Upper Silesia, Poland. Build. Environ. 2020, 177, 106914. [CrossRef] 
37. Voiculescu, M.; Constantin, D.-E.; Condurache-Bota, S.; Călmuc, V.; Roșu, A.; Dragomir Bălănică, C.M. Role of Meteorological Parameters in the Diurnal and Seasonal Variation of $\mathrm{NO}_{2}$ in a Romanian Urban Environment. Int. J. Environ. Res. Public Health 2020, 17, 6228. [CrossRef]

38. Çelik, M.B.; Kadi, İ. The Relation between Meteorological Factors and Pollutants Concentrations in Karabük City; G. U. Journal of Science 2007, 20, 87-95.

39. Dominick, D.; Latif, T.; Juahir, H.; Aris, A.Z.; Zain, S.M. An assessment of influence of meteorological factors on PM and 10 NO at selected stations in Malaysia. Sustain. Environ. Res 2012, 22, 305-315.

40. Elminir, H.K. Dependence of urban air pollutants on meteorology. Sci. Total Environ. 2005, 350, 225-237. [CrossRef]

41. Gasmi, K.; Aljalal, A.; Al-Basheer, W.; Abdulahi, M. Analysis of $\mathrm{NO}_{x}, \mathrm{NO}$ and $\mathrm{NO}_{2}$ ambient levels as a function of meteorological parameters in Dhahran, Saudi Arabia. WIT Trans. Ecol. Environ. 2017, 211, 77-86.

42. Zhou, R.; Wang, S.; Shi, C.; Wang, W.; Zhao, H.; Liu, R.; Chen, L.; Zhou, B. Study on the Traffic Air Pollution inside and outside a Road Tunnel in Shanghai, China. PLoS ONE 2014, 9, e112195. [CrossRef]

43. Habeebullah, T.M.; Munir, S.; Awad, A.A.A.H.; Morsy, E.A.; Abdulaziz, R.S.; Mohammed, A.M.F. The Interaction between Air Quality and Meteorological Factors in an Arid Environment of Makkah, Saudi Arabia. Int. J. Environ. Sci. Dev. 2015, 6, 576-580. [CrossRef]

44. Hosseinibalam, F.; Hejazi, A. Influence of Meteorological Parameters on Air Pollution in Isfahan. In Proceedings of the 3rd International Conference on Biology, Environment and Chemistry, Bangkok, Thailand, 24-25 November 2012; pp. 7-12.

45. Day, D.A.; Wooldridge, P.J.; Cohen, R.C. Observations of the effects of temperature on atmospheric $\mathrm{HNO}_{3}$, ANs, PNs, and $\mathrm{NO}_{x}$ : Evidence for a temperature-dependent $\mathrm{HO}_{\mathrm{x}}$ source. Atmos. Chem. Phys. 2008, 8, 1867-1879. [CrossRef]

46. Kendrick, C.M.; Koonce, P.; George, L.A. Diurnal and seasonal variations of NO, $\mathrm{NO}_{2}$ and $\mathrm{PM}_{2.5}$ mass as a function of traffic volumes alongside an urban arterial. Atmos. Environ. 2015, 122, 133-141. [CrossRef]

47. Liu, F.; Beirle, S.; Zhang, Q.; Dörner, S.; He, K.; Wagner, T. $\mathrm{NO}_{\mathrm{x}}$ lifetimes and emissions of cities and power plants in polluted background estimated by satellite observations. Atmos. Chem. Phys. 2016, 16, 5283-5298. [CrossRef]

48. Ministry of Environment. Polish Journal of Laws Regulation of the Minister of Environment of 13 September 2012, No. 1031-The Levels of Certain Substances in the Ambient Air; Ministry of Environment: Warsaw, Poland, 2012.

49. Oncology Centre. Anual Report. Available online: https://www.coi.pl/wp-content/uploads/2019/09/ Sprawozdanie-Dyrektora-za-rok-2018-Wydruk.pdf. (accessed on 24 September 2020).

50. Baldasano, J.M.; Gonçalves, M.; Soret, A.; Jiménez-Guerrero, P. Air pollution impacts of speed limitation measures in large cities: The need for improving traffic data in a metropolitan area. Atmos. Environ. 2010, 44, 2997-3006. [CrossRef]

51. Keuken, M.P.; Jonkers, S.; Wilmink, I.R.; Wesseling, J. Reduced NOx and PM10 emissions on urban motorways in The Netherlands by 80 km/h speed management. Sci. Total Environ. 2010, 408, 2517-2526. [CrossRef] [PubMed]

52. Punzo, V.; Cascetta, E.; Bonnel, P. Impact on Vehicle Speeds and Pollutant Emissions of a Fully Automated Section Speed Control Scheme on the Naples Urban Motorway. Available online: https://trid.trb.org/view/ 909670 (accessed on 6 October 2020).

53. Cameron, M. Optimum speeds on rural roads based on "willingness to pay" values of road trauma. J. Australas. Coll. Road Saf. 2012, 23, 67-74.

54. Badyda, A. Analysis and Evaluation of the Effects of Selected road Traffic Nuisance on the Urban Environment in Warsaw; Warsaw University of Technology: Warsaw, Poland, 2006.

55. Andrzejewski, M.; Merkisz, J. The effect of CI engine speed on the emission of toxic compounds in the exhaust gases. Combust. Engines 2015, 162, 456-460.

56. Andrzejewski, M. Influence of Driver's Driving Style on Fuel Consumption and Emission of Harmful Substances in Exhaust Gases; Poznan University of Technology: Poznan, Poland, 2013.

57. Cowie, C.T.; Rose, N.; Gillett, R.; Walter, S.; Marks, G.B. Redistribution of traffic related air pollution associated with a new road tunnel. Environ. Sci. Technol. 2012, 46, 2918-2927. [CrossRef]

58. CEDR Conference of European Directors of Roads. Call 2012: Noise ON-AIR Guidance Book on the Integration of Noise in Road Planning. Available online: https://www.cedr.eu/download/Publications/ 2017/CEDR-Contractor-Report-2017-03_Call-2012-Noise_ON-AIR-Guidance-Manual.pdf (accessed on 29 September 2020). 
59. Meneguzzer, C.; Gastaldi, M.; Rossi, R.; Gecchele, G.; Prati, M.V. Comparison of exhaust emissions at intersections under traffic signal versus roundabout control using an instrumented vehicle. Transp. Res. Procedia 2017, 25, 1597-1609. [CrossRef]

60. APCD (Air Pollution Control District) Modern Roundabouts. Available online: https://www.sdapcd. org/content/dam/sdc/apcd/PDF/AirQualityPlanning/Modern-Roundabouts-Traffic-Circles.pdf (accessed on 6 October 2020).

61. Macioszek, E. The application of HCM 2010 in the determination of capacity of traffic lanes at turbo roundabout. Transp. Probl. 2016, 11, 77-89. [CrossRef]

62. Grabowski, R.J. Turbo-roundabouts as an alternative to standard roundabouts with the circular centre island. Roads Bridg. 2012, 11, 215-231.

63. Jaworski, A.; Lejda, K. Emission of pollution from motor vehicles with respect to selected solutions of roundabout intersections. Combust. Engines 2017, 168, 140-144.

64. Silva, A.B.; Mariano, P.; Silva, J.P. Performance assessment of turbo-roundabouts in corridors. Transp. Res. Procedia 2015, 10, 124-133. [CrossRef]

65. Fernandes, P.; Bandeira, J.M. Driving around turbo-roundabouts vs. conventional roundabouts: Are there advantages regarding pollutant emissions? Int. J. Sustain. Transp. 2016, 10, 847-860. [CrossRef]

66. Meneguzzer, C.; Gastaldi, M.; Giancristofaro, R.A. Before-and-After Field Investigation of the Effects on Pollutant Emissions of Replacing a Signal-Controlled Road Intersection with a Roundabout. J. Adv. Transp. 2018. [CrossRef]

67. Brechler, J.; Fuka, V. Impact of Noise Barriers on Air-Pollution Dispersion. Nat. Sci. 2014, 06, 377-386. [CrossRef]

68. CEDR Conference of European Directors of Roads. CEDR Transnational Road Research Programme, Call 2012: Noise: Integrating Strategic Noise Management into the Operation and Maintenance of National Road Networks DISTANCE State-of-the-Art on Secondary Functions for Pavements and Noise Screens. Available online: https://www.cedr.eu/download/other_public_files/research_programme/call_2012/road_ noise/distance/DISTANCE-BRRC-D31-V01-010415-State-of-the-art-on-secondary-functions-of-noisebarriers-and-pavements.pdf (accessed on 21 November 2020).

69. Zouzelka, R.; Rathousky, J. Photocatalytic abatement of $\mathrm{NO}_{\mathbf{x}}$ pollutants in the air using commercial functional coating with porous morphology. Appl. Catal. B Environ. 2017, 217, 466-476. [CrossRef]

70. EUROVIA NOxer ${ }^{\circledR}$. Innovation for sustainable development and Air Quality improvement. In Proceedings of the Sharing the Road 16th World Meeting, Lisbon, Portugal, 25-28 May 2010.

71. Automobile Association Euro Emissions Standards. Available online: https://www.theaa.com/drivingadvice/fuels-environment/euro-emissions-standards (accessed on 21 November 2020).

72. Statistics Poland Environment. 2017. Available online: https://stat.gov.pl/obszary-tematyczne/srodowiskoenergia/srodowisko/ochrona-srodowiska-2017,1,18.html (accessed on 13 November 2020).

73. Statistics Poland Environment. 2013. Available online: https://stat.gov.pl/obszary-tematyczne/srodowiskoenergia/srodowisko/ochrona-srodowiska-2013,1,14.html (accessed on 13 November 2020).

74. Municipal Road Management in Gliwice ZDM Gliwice. Available online: https://zdm.gliwice.pl/ (accessed on 1 October 2020).

75. infogliwice.pl Info Gliwice. Available online: https://infogliwice.pl/ile-samochodow-przejezdza-codziennietunelem-dts-w-gliwicach/ (accessed on 1 October 2020).

76. Burns, J.; Boogaard, H.; Polus, S.; Pfadenhauer, L.M.; Rohwer, A.C.; van Erp, A.M.; Turley, R.; Rehfuess, E.A. Interventions to reduce ambient air pollution and their effects on health: An abridged Cochrane systematic review. Environ. Int. 2020, 135, 105400. [CrossRef]

77. Titos, G.; Lyamani, H.; Drinovec, L.; Olmo, F.J.; Močnik, G.; Alados-Arboledas, L. Evaluation of the impact of transportation changes on air quality. Atmos. Environ. 2015, 114, 19-31. [CrossRef]

78. Hajji, A.M.; Yulistyorini, A.; Yue, H.; Patulak, D.C. Emission factors of $\mathrm{NO}_{\mathrm{x}}$ and PM of heavy construction equipment used in toll road project in Indonesia-Case study: Rembang-Pasuruan Toll Section II. IOP Conf. Ser. Mater. Sci. Eng. 2019, 669. [CrossRef]

79. Wang, X.; Duan, Z.; Wu, L.; Yang, D. Estimation of carbon dioxide emission in highway construction: A case study in southwest region of China. J. Clean. Prod. 2015, 103, 705-714. [CrossRef]

80. Ma, F.; Sha, A.; Lin, R.; Huang, Y.; Wang, C. Greenhouse Gas Emissions from Asphalt Pavement Construction: A Case Study in China. Int. J. Environ. Res. Public Health 2016, 13, 351. [CrossRef] [PubMed] 
81. Quiros, D.C.; Thiruvengadam, A.; Pradhan, S.; Besch, M.; Thiruvengadam, P.; Demirgok, B.; Carder, D.; Oshinuga, A.; Huai, T.; Hu, S. Real-World Emissions from Modern Heavy-Duty Diesel, Natural Gas, and Hybrid Diesel Trucks Operating Along Major California Freight Corridors. Emiss. Control Sci. Technol. 2016, 2, 156-172. [CrossRef]

82. Velders, G.J.M.; Geilenkirchen, G.P.; de Lange, R. Higher than expected NOx emission from trucks may affect attainability of $\mathrm{NO}_{2}$ limit values in the Netherlands. Atmos. Environ. 2011, 45, 3025-3033. [CrossRef]

Publisher's Note: MDPI stays neutral with regard to jurisdictional claims in published maps and institutional affiliations.

(C) 2020 by the authors. Licensee MDPI, Basel, Switzerland. This article is an open access article distributed under the terms and conditions of the Creative Commons Attribution (CC BY) license (http://creativecommons.org/licenses/by/4.0/). 